\title{
Job Insecurity Anomaly on Turnover Intention and Employee Performance in The Organization Heavy Equipment Transportation Services
}

\author{
Mochamad Soelton, Tri Wahyono, Chairiel Oktaviar, Harefan Arief, Eko Tama Putra Saratian, \\ Indah Cahyawati, and Tantri Yanuar Rahmat Syah
}

\section{ABSTRACT}

\begin{abstract}
Human resources are important resources that support organizations in achieving competitive advantage. Therefore, it is important to involve employees to drive the strategic goals of the organization. Heavy equipment transportation services in the era of globalization are expected to face increasingly fierce competition. Therefore, the quality of the organization must be considered. This is inseparable from the role of human resources who will be required to carry out their duties and functions properly. The purpose of this research is to examine and analyze job insecurity, compensation, and work conflicts on the turnover intention and the employe performance. This study employs samples consisted of all employes who work at PT. Tangguh Jaya Bersama with a total population of 50 employees. The results indicate that variable job insecurity, and work conflicts have a positive and significant impact on turnover intention. Whereas the compensation has a negative and significant on turnover intention. The variable compensation and work conflicts have a significantly positive on employee performance, whereas the jobs insecurity have a significantly negative on employee performance. The variable turnover intention has a significantly negative on employee performance.
\end{abstract}

Keywords: Job Insecurity, Compensation, Work Conflicts, Turnover Intention, Employee Performance.

\section{INTRODUCTION}

In organization, human capital is a very important factor for the effectiveness of its running activities within a company or organization. Every company whatever its shape and type, will require human resources who have the ability to think, the task is also in accordance with the needs of the company [1]-[4]. Human resources are also very important for the company or organization in the work and employees who can help for the company it reaches. Especially in the current era of the future, the world is always changing, marked by the increase in technological developments in all fields. To respond to these changes, companies are required to manage and improve the quality of HR (competency-based HR) through increasing the knowledge, skills and abilities of $\mathrm{HR}$ to the HR involved in the company's processes or
Submitted : March 20, 2021

Published : April 30, 2021

ISSN: 2507-1076

DOI: $10.24018 /$ ejbmr.2021.6.2.822

Mochamad Soelton*

Management Department, Faculty of Economics and Business, Mercu Buana University, Indonesia.

(e-mail: soelton@mercubuana.ac.id) Tri Wahyono

Management Department, Faculty of Economics and Business, Mercu Buana University, Indonesia.

Chairiel Oktaviar

Management Department, Faculty of Economics and Business, Mercu Buana

University, Indonesia.

Harefan Arief

Management Department, Faculty of Economics and Business, Mercu Buana University, Indonesia.

Eko Tama Putra Saratian

Management Department, Faculty of Economics and Business, Mercu Buana University, Indonesia.

Indah Cahyawati

Management Department, Faculty of Economics and Business, Mercu Buana University, Indonesia.

Tantri Yanuar Rahmat Syah

Management Department, Faculty

Economics and Business, Esa Unggul

University, Indonesia.

*Corresponding Author

activities to form knowledge-based $\mathrm{HR}$ that requires expertise and expertise [5], [6]. [7] sates that human resource management is the science and also art in terms of managing the roles and relationships of the workforce so that they are effective and efficient in helping to realize the goals of the company, employees and according to [8], the good and the bad of human resources itself can be assessed by seeing how much fast input and output that occur at the company or what is also known as turnover intention. [5], [6].

A company can be said to have good human resources when the input and output that occur in the company does not occur significantly. And from research conducted [9], said that quality human resources have a positive effect on the performance and progress of an organization. According to [10], one of the human resource problems that often arise and can hinder performance is the employee turnover rate. The 
desire to move (turnover intention) is an initial signal of employee turnover within the organization.

According to [11], they argue that in order for the company's goals to be achieved, the company must concern to and maintain its workers properly so that workers who have good qualifications in the company do not have the desire to move or even leave the company (turnover intention) because they do not get enough attention from the company. Likewise, according to [12], in his research, he said that the high value of turnover intention that have an impact on the employee performance.

The absence of job satisfaction that is initiated by an employee that will affect the employee's condition. Employees experience an increasing sense of job insecurity due to instability in their employment status and increasingly unpredictable income levels, as a result the intention to change jobs (turnover) tends to increase, as well as factors of age, length of work, and organizational culture also an important thing, in the event of a turnover intention.

So that according to [13] said that performance has a negative significantly effect on intention to move, in this case there is that if employee performance increases, the level of intention to move will decrease. Several factors can cause the desire to change jobs (turnover intention), one of the factors is job insecurity [14]. In addition, [13] defines job insecurity as a psychological condition of a person (employee) who shows a feeling of confusion or insecurity due to changing environmental conditions (perceived impermanance).

Compensation can be interpreted as the remuneration received entirely by employees in terms of carry out their work, and the money provides by company, awards or allowances which in order motivating employees to participate in development activities, company growth and also support employee commitment [5], [6].

PT. Tangguh Jaya Bersama has the highest turnover, which occurred in July and September 2018 as many as 4 employees left the company for different reasons. The reasons found after conducting the survey were incompatibility with benefits / income, wanting to seek other experiences, decreased attendance, marriage and personal reasons. There is also an assessment of human resources that can be based on the performance of each employee or the individual himself.

In this study, researchers saw that there are several factors that can affect turnover intention and performance that occur in a company, one of which is job insecurity. In addition to job insecurity factors that are considered to be able to influence turnover intention and performance, other factors that can affect these two things are compensation. According to [15] compensation is what employees received, whether in the form of money or non-money as remuneration provided for employee efforts (employee contributions) provided to the organization.

With the phenomenon above, compensation will cause work conflicts and is considered to be able to affect the turnover intention and performance of an employee in the company. Work conflicts can be motivated by differences in characteristics of individuals when interacting.

These differences concern knowledge, abilities, customs, beliefs, and so on. According to [16]; states that work conflict is two or more members or groups mismatched in a company that have to share work activities and also the fact where they have different goals, status, perceptions or values. Thus, job insecurity, compensation, and work conflict are important indicators in determining whether or not turnover intention and performance are good.

\section{LITERATURE REVIEW}

\section{A. Job Insecurity}

According to Lewis in [13], interpreting job insecurity as a psychological condition of a (employee) who shows a feeling of confusion or insecurity due to changing environmental conditions. Likewise, according to [17], interpreting job insecurity as a condition of powerlessness in order to maintain the desired continuity in a work threatening situation. Job insecurity is also translated as a feeling of anxiety, stress, worry, tension and uncertainty feeling in terms of the nature and existence of workers perceived.

According to Ashford et al in [18], the factors that influence job insecurity are demographic characteristics that can affect including age, gender, years of service, marital status, and education level; Unclear roles related to how much information employees have regarding job demands and work procedures; Work environment conditions, is a source of threats that are outside the contor of the individual. Covering, mergers, downsizing, reorganization and use of new technology; Individual differences, namely there is a locus of control and individual values.

\section{B. Compensation}

According to [7], compensation is income included money or indirect goods received by employees as compensation for providing services to the company. Meanwhile, according to [19], employee compensation refers to payment or reward given to employees and arises from the employee's work. According to [15], compensation is what received by employees, in the form of money or non-money as remuneration provided for employee efforts (employee contributions) provided to the organization.

Based on the opinion of experts, compensation shows an interaction between employees and the organization in the terms of reciprocation of services issued by the awards and employees from the organization, with the realization of wages or other facilities and the abilities they have devoted to a certain period as the contribution in achieving the goals of organizational. The compensation system should satisfy the needs of employees, ensure fair treatment of them in terms of compensation and reward their performance. If the compensation system has been able to create conditions like the one above, employees will be happy to fulfill the request of the management to work optimally. In simple terms, compensation satisfaction will lead to increased performance for employees.

\section{Work Conflicts}

According to [20], conflict is antagonistic psychological relations, related to non-adjustable goals, mutually exclusive interests, hostile emotional attitudes, and different value structures. [7] argues that conflict is unhealthy competition based on emotional and ambition attitudes to win. [21] defines work conflict, namely two or more members or 
groups (in an organization / company) mismatched that must share limited resources or work activities because of they have different goals, status, values, or perception.

\section{Turnover Intention}

According to [22], he states that turnover intention is a condition in which workers have a conscious intention or tendency to seek another job as an alternative in a different organization and turnover is the driving force for the departure of workers from their place of work. Then according to [23], stated that the desire of employees to leave the company is largely determined based on emotional attitudes. According to [24] turnover intention is the individual's result for continuation evaluation of the relationship with the company they work for, but has not been realized in real action.

\section{E. Employee Performance}

According to [25] employee performance is the result of work, both of quality and quantity achievement in carrying out the duties in accordance with the role, responsibilities assigned to employee. According to [26] performance is a performance translation that means the work result of employee, a process or a management as a whole, where the results must be shown concrete and measurable evidence.

Meanwhile, according to [27] performance is of a person's work result and work behavior in a period of usually 1 year. [28], employee performance is defined as an output, efficiency and effectiveness expression are often related to the productivity. From the definition according to the experts above, it can be said that employee performance is the work achieved by person and/or group in an institution in line with their respective responsibilities in the framework of achieving the goals of the institution in accordance with certain principles.

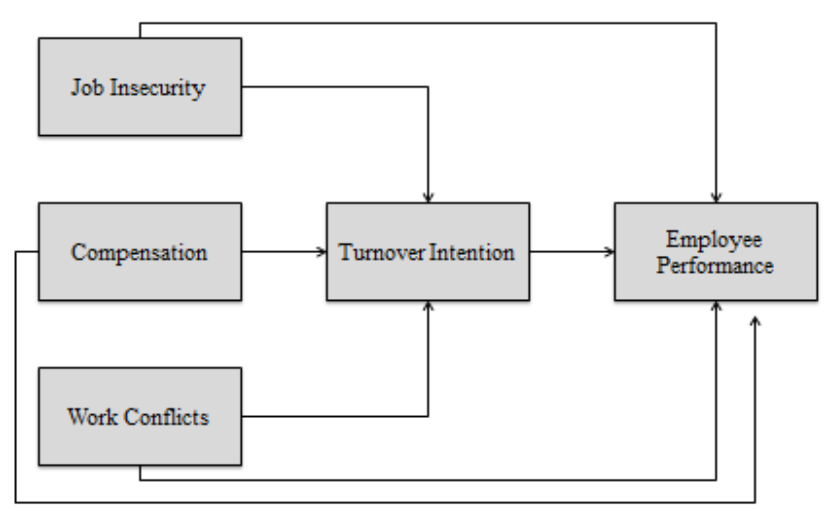

Fig. 1. Research Framework.

\section{Methodology}

The process of this study begins with the activities of problems identifying at the research site, conducting problem formulation and gathering basic theories to strengthen the foundation of each variable. Furthermore, the preparation of methods in data collection, instrument preparation and testing techniques are carried out. Seeing the characteristics of the existing population and the purpose of this study, the sampling technique in this study is saturated sampling, namely the determination of respondents from the all of population.

In this study using a quantitative approach in which the survey through a questionnaire method using the Partial Least Square (PLS) methodology and descriptive analysis using SPSS Statistics 25. The population in this study is the all employes who work at PT. Tangguh Jaya Bersama with a total population of 50 respondent.

\section{RESULTS AND DISCUSSION}

\section{A. Results}

Seeing the $\mathrm{R}$ Square value $\left(\mathrm{R}^{2}\right)$ which is a testing for Goodness of Fit (GoF) Model. In assessing models with PLS begins to see $\mathrm{R}$ Square $\left(\mathrm{R}^{2}\right)$ for each dependent latent variables. According to Chin (1998), the values of $\mathrm{R}$ square are 0,67 (strong), 0.33 (moderate) and 0.19 (weak). The relevance of the predicted value (Q squared) at 0,02 (small), 0.15 (medium) and 0.35 (large). Testing Goodness of Fit Structural models in the inner model using predictive relevance $\left(\mathrm{Q}^{2}\right)$. Q-Square $\left(\mathrm{Q}^{2}\right)$ value greater than 0 (zero) indicates that the model has a predictive relevance value.

The measurement model analysis in this case aims to test the validity and reliability of each dimension and the indicators used to measure each of the previously constructed variables. Analysis of the measurement model can be explained by explaining the discriminant validity value by looking at the square root value of Average Variance Extracted (AVE) with a suggested value above 0.5, loading factor (>0.5), building validity and composite reliability (Cronbach's Alpha> 0.70).

\begin{tabular}{lcccc}
\multicolumn{5}{c}{ TABLE I: GoODNESS OF FIT MODEL (GoF) } \\
\hline \multicolumn{1}{c}{ Variable } & AVE & $\begin{array}{c}\text { Composite } \\
\text { Reliability }\end{array}$ & $\begin{array}{c}\text { Cronbac's } \\
\text { Alpha }\end{array}$ & $\begin{array}{c}\text { R } \\
\text { Square }\end{array}$ \\
\hline Job Insecurity & 0.698 & 0.811 & 0.747 & - \\
Compensation & 0.730 & 0.764 & 0.806 & - \\
Work Conflicts & 0.619 & 0.733 & 0.893 & - \\
Turniover Intention & 0.778 & 0.864 & 0.771 & 0.776 \\
Employee & 0.628 & 0.796 & 0.738 & 0.849 \\
Performance & & & & \\
\hline
\end{tabular}

The $\mathrm{R}^{2}$ value indicates that the criteria are strong, it is concluded that the proposed model is supported by empirical research in which the model is classified as an appropriate model. The AVE values are $>0.5$, which indicates the variables in the meet of the model of discriminant validity criteria. The composite reliability and Cronbach's Alpha value for each variable is $>0.70$ which means all variables are classified as reliable.

The measurement results based on analysis of data processing on dimensional models based indicators show that the overall indicator is processed on top of that is in Table II were classified as invalid where the majority of value loading factor greater than $>0,50$ (over 0,50 ). 
TABLE II: LOADING FACTOR BETWEEN LATENT VARIABLES AND

\begin{tabular}{|c|c|c|c|}
\hline \multicolumn{4}{|c|}{ DIMENSIONS } \\
\hline Variable & Indicator & $\begin{array}{c}\text { Loading Factor } \\
(\lambda)\end{array}$ & Remark \\
\hline \multirow{3}{*}{ Job Insecurity } & JI1 & 0.581 & Valid \\
\hline & JI4 & 0.681 & Valid \\
\hline & JI5 & 0.663 & Valid \\
\hline \multirow{3}{*}{ Compensation } & $\mathrm{C} 2$ & 0.560 & Valid \\
\hline & C3 & 0.790 & Valid \\
\hline & $\mathrm{C} 4$ & 0.893 & Valid \\
\hline \multirow{3}{*}{ Work Conflict } & WC1 & 0.688 & Valid \\
\hline & WC4 & 0.608 & Valid \\
\hline & WC5 & 0.853 & Valid \\
\hline \multirow{3}{*}{ Turnover Intention } & $\mathrm{TI} 3$ & 0.601 & Valid \\
\hline & TI4 & 0.682 & Valid \\
\hline & TI5 & 0.883 & Valid \\
\hline \multirow{4}{*}{$\begin{array}{c}\text { Employee } \\
\text { Performance }\end{array}$} & EP1 & 0.743 & Valid \\
\hline & EP2 & 0.544 & Valid \\
\hline & EP4 & 0.667 & Valid \\
\hline & EP6 & 0.740 & Valid \\
\hline
\end{tabular}

TABLE III: THE RESULT OF HYPOTHESIS TESTING

\begin{tabular}{ccccc}
\hline Hypothesis & $\begin{array}{c}\text { Original } \\
\text { Sample }\end{array}$ & $\gamma \beta$ & $\begin{array}{c}\text { T- } \\
\text { Statistics }\end{array}$ & Remark \\
\hline $\mathrm{JI} \rightarrow \mathrm{TI}$ & 0.563 & 0.076 & 3.904 & Positive - Significant \\
$\mathrm{JI} \rightarrow$ EP & -0.392 & 0.055 & 3.737 & Negative - Significant \\
$\mathrm{C} \rightarrow \mathrm{TI}$ & -0.641 & 0.084 & 4.790 & Negative - Significant \\
$\mathrm{C} \rightarrow$ EP & 0.470 & 0.044 & 5.908 & Positive - Insignificant \\
$\mathrm{WC} \rightarrow$ TI & 0.364 & 0.073 & 3.379 & Positive - Insignificant \\
$\mathrm{WC} \rightarrow$ EP & 0.311 & 0.040 & 4.105 & Positive - Significant \\
$\mathrm{TI} \rightarrow$ EP & -0.442 & 0.078 & 6.470 & Negative - Significant \\
\hline
\end{tabular}

\section{B. Discussion}

\section{The influence of job insecurity towards turnover} intention

Regarding the testing of hypothesis, the results obtained tstatistic job insecurity of turnover intention of 3.904 and the value of the original sample of 0.563 . T-statistic value is more substantial than the value of the t-table is 1.96 and the value of the original sample shows the value positive, the result describes that influential jobs insecurity positive and significant impact on turnover intention. Positive values in the original sample indicate the direction of a positive relationship between the jobs insecurity on turnover intention. The results of this research are supported by research [1], [29], [30].

2. The influence of compensation towards turnover intention

Regarding the hypothesis test the impact of the compensation on turnover intention obtained the value of $t-$ statistic 4.790 and the original sample value -0.641 . The value of t-statistic > the t-table value that is 1.96 and the value of original sample indicates the value negative, this result shows that compensation is influential significant negatively impact on turnover intention. The results of this study are supported by research [1], [29]-[31].

3. The influence of work conflicts towards turnover intention

Work conflicts is influential negative and significant to turnover intention Obtained the t-statistic value of 3.379 and the value of original sample of 0.364 . The t-statistic value $>$ the t-table value that is 1.96 and the value of original sample indicates positive, this result shows that compensation is influential positive and significant impact on turnover intention. The results are supported by [1], [29], [30], [32], [33].

\section{The influence of jobs insecurity towards employee} performance

Furthermore, based on the hypothesis testing the effect of jobs insecurity on employee performance the results obtained value of t-statistic 3.737 and the value of original sample 0.392 . The t-statistic value $>$ t-table value that is 1.96 and the value of original sample indicates the negative, this result shows that influential jobs insecurity negative and significant impact on employee performance. The results of this study are supported by [1], [29], [30], [32], [33].

5. The influence of compensation towards employee performance

Furthermore, regaring the hypothesis testing the effect of compensation on employee performance the results obtained value of t-statistic 5.908 and the value of original sample 0.470 . The t-statistic value $>$ the $t$-table value that is 1.96 and the value of original sample indicating the positive, result shows influential compensation positive and significant impact on employee performance. Based on the results of [1], [29], [30], [31].

6. The influence of work conflicts towards employee performance

Furthermore, regarding the hypothesis testing the effect of work conflicts on employee performance the results obtained value of t-statistic 4.105 and the value of original sample 0.311 . The t-statistic value $>$ the $t$-table value that is 1.96 and the value of original sample indicating the positive value, result shows influential work conflicts significantly positive impact on employee performance. Based on the results of [1], [29]-[31].

7. The influence of turnover intention towards employee performance

Furthermore, regarding the hypothesis testing the effect of turnover intention on employee performance the results obtained value of t-statistic 6.470 and value of the original sample -0.442 . The t-statistic value $>$ the t-table value that is 1.96 and the value of original sample indicating the negative value, result shows that influential turnover intention have significantly negative impact on employee performance. Based on the results of [1], [29]-[31].

\section{CONCLUSION, IMPLICATION AND LIMITATION}

\section{A. Conclusion}

The aim of this research is to analyze the impact of Job Insecurity, Compensation and Work Conflict on Turnover Intention and Employee Performance of PT. Tangguh Jaya Bersama. Based on the analysis of the data and the discussion that has been put forward, it can be stated several research conclusions as follows:

1. Job Insecurity has a significantly positive effect on Turnover Intention at PT. Tangguh Jaya Bersama. This means that if the insecurity in working in a company is good, then the level of desire to leave the employee will be less or lower.

2. Compensation has a significantly negative effect on Turnover Intention of PT. Tangguh Jaya Bersama. This means that if the compensation in a company is low or bad, the level of willingness to leave the company will also be higher. 
3. Work Conflict has a significantly positive effect on Turnover Intention of PT. Tangguh Jaya Bersama. This means that if a work conflict in a company is low or may not occur, then the level of willingness to leave the company is also getting lower.

4. Job Insecurity has a significantly negative effect on the performance of PT. Tangguh Jaya Bersama. This means that if the insecurity in work in a company is low, then the level of performance in a company is also low.

5. Compensation has a significantly positive effect on the performance of PT. Tangguh Jaya Bersama. This means that if the compensation in a company is good, then the level of performance in a company will also be good.

6. Work Conflict has a significantly positive effect on the performance of PT. Tangguh Jaya Bersama. This means that if a work conflict in a company is good or does not occur, then the level of performance in a company will also be good.

7. Turnover Intention has a significantly positive negative effect on the performance of PT. Tangguh Jaya Bersama. This means that if the level of desire to leave employees in a company is low, then the level of performance in a company will also be good.

\section{B. Implication}

The study of this research has concluded both of theoretical and practical implications:

1. The company pays more attention to the level of achievement of existing career paths in the company such as the level of promotion for employees who work well, this will make employees feel comfortable and can reward employees who work well, so that employees can feel comfortable at work if they work well.

2. Companies to be fair in the distribution of work to each employee, so that the level of burden received by employees is in accordance with the level of ability and position received by the employee and provides a salary according to the employee's tenure, so that employees can work harder and better.

3. Companies are able to establish communication between employees and be able to maintain good relations between employees, so that employees feel united and can work well between teamwork.

\section{LIMITATION}

This research may not cover all variables and issues that might be encountered by the employee performance.So that in the future, if there are researchers who want to examine employee performance, they can use other variables outside of this study with a wider area of respondents and others companies.

\section{REFERENCES}

[1] Soelton, M., P Amaelia HP. Dealing with Job Insecurity, Work Stress, and Family Conflict of Employees. 4th Int Conf Manag Econ Bus (ICMEB 2019) 2020;2020/2:(167-174). atlantis-press.com.

[2] Soelton, M., S Himawan, L Fazriyanti, S Ria IG. Visionary Leadership Structure: Stress Levels On Performance In Technology and Communications Industry. Forum Manaj Indones 10-Palembang 2018;10 (Novemb:508.

[3] Soelton, M., S Ria FA. Effect of Organizational Culture, Job Satisfaction, and Engagement on Employee Performance in
Government Company. Proceeding Int Conf Manag Econ Bus Univ Mercu Buana (ICMEB 2018) 2018; Jilid 2018.

[4] Mangkunegara AAAP. Manajemen Sumber Daya Manusia Perusahaan. Bandung. Bandung: PT Remaja Rosdakarya; 2011.

[5] Soelton, M., \& Nugrahati T. How Complaining Behaviors Effect on Coping Stress and Anxiety. Int J Saudi J Bus Manag Stud 2018;3(6):623-8.

[6] Jumadi, M Soelton TN. Bagaimanakah Beban Kerja dan Stres Kerja Mempengaruhi Organizational Citizenship Behavior (OCB) dan Kinerja Karyawan PT. Multitek Indopanca Jakarta. Forum Manaj Indones 10-Pelembang 2018;10 (Novemb:501.

[7] Hasibuan M. Manajemen Sumber Daya Manusia. Jakarta: PT Bumi Aksara; 2012.

[8] Soelton, M \& Atnani M. How Work Environment, Work Satisfaction, Work Stress on The Turnover Intention Affect University Management. J Manaj Bisnis Indones 2018;5 (3).

[9] Brury M. Pengaruh Kepemimpinan, Budaya Organisasi Motivasi Kerja Dan Kepuasan Kerja Terhadap Kinerja Pegawai Pada Kantor SAR Sorong. J Ris Bisnis Dan Manaj 2016;Vol.4, No.

[10] Ajiputra, S. M., \& Yuniawan A. Analisis Pengaruh Job Insecurity, dan Kepuasan Kompensasi Terhadap Turnover Intention Serta Dampaknya Pada Kinerja Karyawan. Diponegoro J Manag 2016; Vol. 5, No.

[11] Septiari, N. K., \& Ardana IK. Pengaruh Job Insecurity dan Stres Kerja Terhadap Turnover Intention Karyawan Pada Hotel Asana Agung Putra Bali. J Manaj Unud 2016; Vol. 5, No.

[12] Asmara AP. Pengaruh Turnover Intention terhadap Kinerja Karyawan di Rumah Sakit Bedah Surabaya. J Adm Ekon 2017; Vol. 5, No.

[13] Andrinirina, M., Sudarsih \& D. Pengaruh Lingkungan Kerja, dan Job Insecurity terhadap Kinerja dan Turnover Intention on Royal Hotel n' Lounge Jember. J Ilm 2015;Vol. 3, No:68-75.

[14] Audina, Vika., Kusmayadi T. Pengaruh job insecurity dan job stress terhadap turnover intention (Studi Pada Staff Industri Farmasi Lucas Group Bandung). J Sains Manaj Akunt 2018; Volume X N.

[15] Gaol J. A to Z Human Capital Manajemen Sumber Daya Manusia. Jakarta: Grasindo; 2015.

[16] Syamsu, Nadya, Soelton, M., \& Nanda A. Bagaimanakah Konflik Peran Dan Beban Kerja Mempengaruhi Kinerja Karyawan Dengan Burnout Sebagai Variabel Intervening. J Ilmu Manaj Bisnis 2019; Vol.5, No.

[17] Wening N. Pengaruh Ketidakamanan Kerja Sebagai Dampak Restrukturisasi Terhadap Kepuasan Kerja, Komitmen Organisasi Dan Intensi Keluar Survivor. J Kinerja 2011; Vol.9, No.

[18] Wijayanti PS. Hubungan Antara Job Insecurity dan Konflik Peran dengan Performansi KerjaKaryawan di Balai Besar Wilayah Sungai Bengawan Solo. J Ilm Psikol Candrajiwa 2012; Vol.1, No.

[19] Dessler G. Manajemen Sumber Daya Manusia (edisi kesepuluh). Jakarta: PT Indeks; 2010.

[20] Soetopo H. Perilaku Organisasi. Bandung: PT Remaja Rosdakarya; 2012.

[21] Rivai V. Manajemen Sumber Daya Manusia Untuk Perusahaan Dari Teori ke Praktik. Jakarta: Raja Grafindo Persada; 2011.

[22] Abdillah F. Hubungan Kohevitas Kelompok Dengan Intensi Turnover Intention Pada Karyawan. J Soc Ind Psychol 2012;Vol.1, No.

[23] Green, \& al E. Is Job Quality Becoming More Unequal? Ind Labor Relations Rev 2013; Vol.66 No.:753-84.

[24] Mobley W. Pergantian Karyawan Sebab Akibat dan Pengendaliannya. Jakarta: Pustaka Binaman Pressindo; 2011.

[25] Mangkunegara A. Manajemen Sumber Daya Manusia Perusahaan, Cetakan Kedua Belas. Bandung: PT. Remaja Rosda Karya; 2015.

[26] Sedarmayanti. Manajemen Sumber Daya Manusia. Bandung: Refika Aditama; 2013.

[27] Kasmir. Manajemen Sumber Daya Manusia (Teori dan Praktik). Jakarta: PT. Raja Grafindo Persada; 2016.

[28] Gomes. Manajemen Sumber Daya Manusia. Yogyakarta: Andi Offset; 2010.

[29] Soelton M, Amaelia P, Prasetyo H. Dealing with Job Insecurity, Work Stress, and Family Conflict of Employees, 2020. https://doi.org/10.2991/aebmr.k.200205.031.

[30] Soelton, M., Nicko Alexander Visano, Irfan Noviandy Aulia, Mugiono, Tantri Yanuar Rahmat Syah Lecturer SAF. Work Insecurity Enhances Work Stress and Burnout in Indonesian Railway Industry. Int J Bus Manag 2020; Vol. 8:SSN 2321-8916 www.theijbm.com.

[31] Nanda A, Soelton M, Luiza S, Saratian ETP. The Effect of Psychological Work Environment and Work Loads on Turnover Interest, Work Stress as an Intervening Variable 2020;120:225-31. https://doi.org/10.2991/aebmr.k.200205.040.

[32] Suzabar, D.F. M Soelton, M Umar JT. Recognizing How the Time Demands of Work Influences the Turnover Intention in Banking Industry. 4th Int Conf Manag Econ Bus (ICMEB 2019) 2020;2020/2:(40-45). www.atlantis-press.com. 
[33] Lee C-C, Huang S-H, Zhao C-Y. Asian Economic and Financial Review 2(7):866-875 A study on factors affecting turnover intention of hotel empolyees 2010;2:866-75. 